\title{
Influence of Pilates Method on Nonspecific Lumbar Pain
}

\section{Influência do método pilates na dor lombar não específica}

\author{
Ana Carla Schimidt ${ }^{1}$ Paula de Oliveira Herzinger ${ }^{2}$ Danielle Pacheco Matias ${ }^{2}$ Leonardo C. Welling ${ }^{3(0)}$ \\ 1 Postgraduate Program in Health Sciences, Universidade Estadual de \\ Ponta Grossa, Ponta Grossa, Paraná, Brasil \\ 2 Universidade Estadual de Ponta Grossa, Ponta Grossa, Paraná, Brasil \\ ${ }^{3}$ Department of Neurosurgery, Universidade Estadual de Ponta \\ Grossa, Ponta Grossa, Paraná, Brasil \\ Arq Bras Neurocir 2020;39(4):300-305. \\ Address for correspondence Leonardo C. Welling, MD, PhD, Rua \\ Tiradentes, 976, Sala 1, Centro, Ponta Grossa, PR, Brazil \\ (e-mail: leonardowelling@yahoo.com.br).
}

\begin{abstract}
Keywords

- pilates

- low back pain

- physiotherapy
\end{abstract}

\section{Resumo}

received

March 30, 2020

accepted

July 7, 2020
Low back pain is defined as pain located between the lower rib cage and the gluteal folds, and its etiology is multifactorial, considerably affecting quality of life. The aim of this literature review was to analyze the influence of the Pilates method on the symptoms of patients with nonspecific low back pain, which is considered a promising treatment for this type of pathology. A narrative review of the literature was carried out using the PubMed, Pedro, Scopus and Scielo databases. To perform the search, Pilates AND Low back nonspecific AND Pain were used as keywords. Articles published in the last 5 years, randomized clinical trials that verified the influence of the Pilates method in adult individuals with unspecified low back pain and full text in English were included. Of the 77 articles identified, 7 articles met the inclusion criteria, 7 analyzed the primary outcomes of pain intensity and disability, 5 articles compared Pilates with other rehabilitation techniques and 2 studies compared the effectiveness of Pilates solo with Pilates apparatus. It was concluded that all the techniques that were compared with Pilates are effective, being difficult to affirm the superiority of Pilates over them in relation to the reduction of pain and disability and improvement of quality of life. However, the Pilates method has shown good results in pain perception and intensity, functional capacity, fear of movement and the idea that movement can worsen your condition, muscle strength, range of motion and flexibility.

A lombalgia é definida como dor localizada entre caixa torácica inferior e as pregas glúteas, e sua etiologia é multifatorial, afetando consideravelmente a qualidade de vida. O objetivo da presente revisão de literatura foi analisar a influência do método Pilates na sintomatologia de pacientes com dor lombar não específica, sendo este considerado um tratamento promissor para este tipo de patologia. Foi realizado uma revisão narrativa da literatura utilizando as bases de dados PubMed, Pedro, Scopus e Scielo. Para realizar a busca, foram utilizadas como palavras-chave Pilates AND Low back nonspecific AND Pain. Foram incluídos artigos publicados nos últimos 5 anos, ensaios clínicos randomizados que verificaram a influência do método Pilates em indivíduos adultos com dor lombar não especifica e texto completo em inglês. Dos 77 artigos identificados, 7 artigos satisfizeram os critérios de inclusão, os 7 analisaram os 
desfechos primários de intensidade da dor e incapacidade, 5 artigos compararam o Pilates com outras técnicas de reabilitação e 2 estudos compararam a efetividade do Pilates solo com o Pilates aparelho. Concluí-se que todas as técnicas que foram comparadas com o Pilates são eficazes, sendo difícil afirmar a superioridade do Pilates sobre elas em relação à redução da dor e incapacidade e melhoria da qualidade de vida.

Palavras-chave

- pilates

- dor lombar

- fisioterapia
Contudo, o método Pilates tem demonstrado bons resultados na percepção e intensidade de dor, na capacidade funcional, no medo do movimento e na ideia de que o movimento pode piorar o seu quadro, na força muscular, amplitude de movimento e flexibilidade.

\section{Introduction}

Low back pain is a substantial health problem and is considered a more prevalent musculoskeletal condition in developed countries. ${ }^{1}$ This condition results in functional limitations, pain, and general disability, significantly increasing socioeconomic costs due to interventions and treatment and abstention from work. ${ }^{2,3}$ Low back pain is defined as pain located between the lower ribcage and the gluteal folds, and its etiology is multifactorial and is associated with age, sex, smoking, alcoholism, body weight, social class, psychological factors, education, mechanical trunk balance, physical activity, and labor. ${ }^{2}$

Lumbar involvement is classified into specific spinal pathology, nerve root pain, and nonspecific low back pain, ${ }^{4}$ and by duration as acute, subacute, and chronic. ${ }^{3}$ Epidemiologic studies show that $\sim 65$ to $90 \%$ of the adult population will experience low back pain at some point in life, with nonspecific low back pain being present in $90 \%$ of these cases. ${ }^{1,4}$ The prognosis of these patients is favorable, a small portion of individuals seek care from a health professional to reduce symptoms, which ends up improving pain, disability, and short-term quality of life (QOL). ${ }^{2,5}$ Treatment for low back pain may be conservative, pharmacological, surgical, and rehabilitation. Usually the first recommended treatment option is onpharmacological, such as exercises, motor control exercises, Pilates, Tai Chi, Yoga, and other therapies. ${ }^{4,5}$ When exercise is compared with other treatments or no treatment, pain is reduced, and functionality is improved in patients with nonspecific chronic low back pain, ${ }^{6}$ unlike nonspecific acute lower back pain where exercise is not as effective. $^{4}$

Currently, an exercise program option has been gaining prominence, the Pilates method, which includes stretching exercises and muscle strengthening based on Contrology. ${ }^{7}$ The method was created by Joseph Hubertus Pilates during the First World War, to improve and rehabilitate physical abilities. ${ }^{8}$ It is based on six principles (centralization or powerhouse, concentration, control, precision, breathing, and fluidity) and can be performed on the ground or in appliances. ${ }^{9}$ Because it avoids excessive impact and pressure on the muscles, joints, and tissues, there is a reduction in the characteristic signs and symp- toms of these patients, but there is conclusive evidence that the Pilates method is better than other exercise programs. ${ }^{4,10,11}$

Given the limited scientific evidence on the superiority of Pilates over other types of exercise, the present literature review aims to analyze the influence of the Pilates method on the symptomatology of patients with nonspecific low back pain, which is considered a promising treatment for this type of pathology.

\section{Methods}

A systematic review was performed using the PubMed, Scopus, and Scielo databases. To perform the search, we used as keywords Pilates AND Low back nonspecific AND pain. We included articles published in English in the last 5 years. All of them were randomized controlled trials that verified the influence of the Pilates method on adult individuals with nonspecific low back pain. Exclusion criteria were observational and prospective studies, case reports, and systematic reviews. The flowchart shows the selection of studies. ( - Fig. 1) The primary outcomes were pain intensity and disability, and the secondary outcomes are recovery and method effect.

\section{Results}

In total, seven articles met the inclusion criteria and were considered in the review. Seven analyzed the primary outcomes of pain intensity and disability. Five articles compared Pilates with other rehabilitation techniques, and two studies compared the effectiveness of Mat Pilates with the Pilates appliance.

- Table 1 summarizes the articles included in the research, comparing different patient samples, interventions, and outcomes in the treatment of nonspecific low back pain.

\section{Discussion}

The results found were grouped according to the effects on these results: pain intensity, disability and kinesiophobia, muscle strength, flexibility and range of motion, QOL, and perceived effects and satisfaction with treatment. 


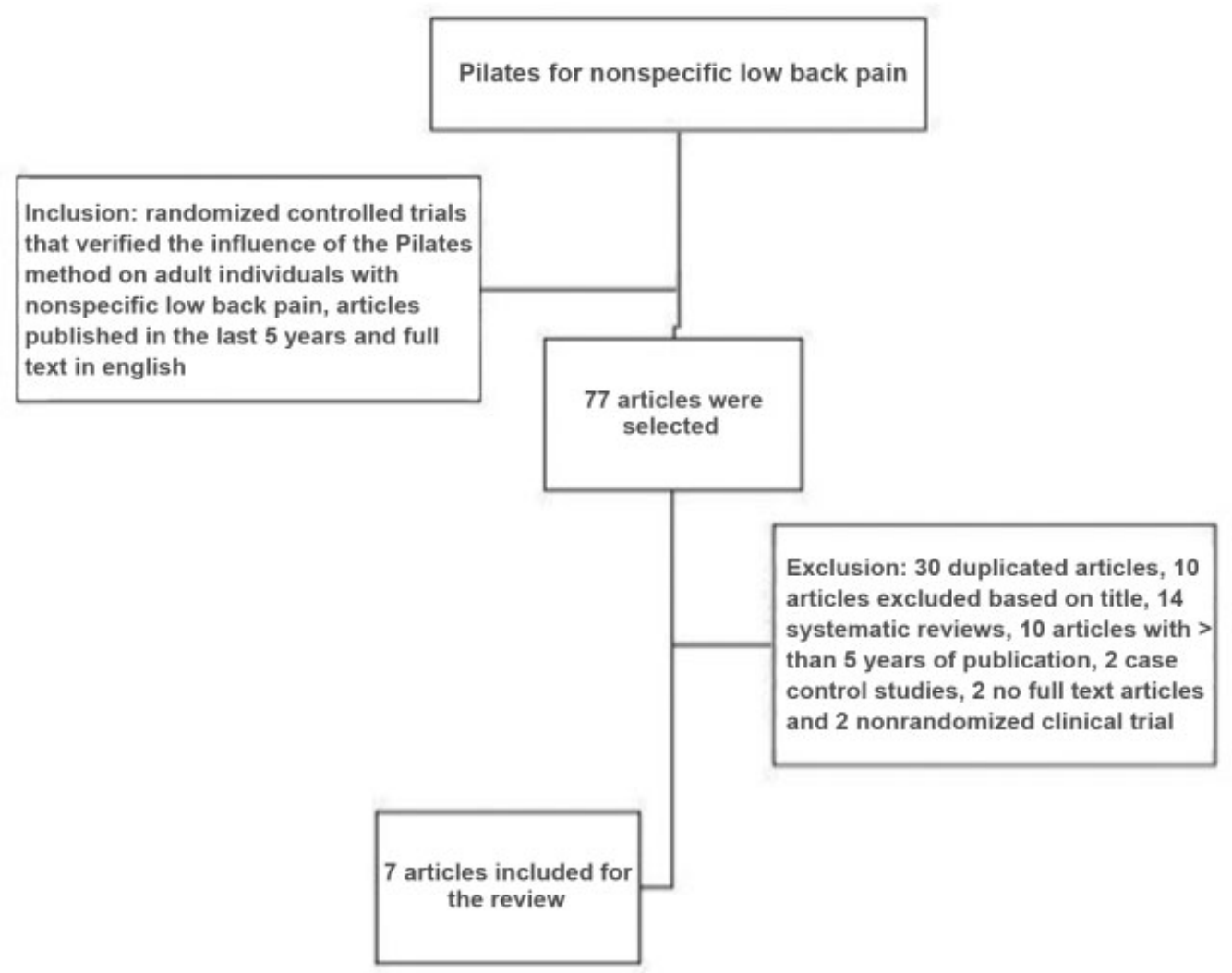

Fig. 1 Flowchart.

\section{Pain Intensity}

Pain is the most prominent symptom of low back pain. Therefore, it is imperative to determine how to improve it. The most used instruments to measure this symptom are the visual analog scale (VAS) and the numerical classification scale (NRS). ${ }^{12}$

The article by da Luz et al compares the Pilates solo method with the Pilates apparatus. Pain intensity was assessed at short term (6 weeks) and medium-term (6 months) after randomization. In the intragroup comparison, a significant difference was found for pain $(p<0.001)$ in the medium term. In the comparison between groups, there was no significant difference for this symptom in the short and medium-term. ${ }^{13}$ Natour et al, who compared the intervention group with the control group over time, found a significant difference that favored the Pilates group concerning pain $(p<0.001)$. Pain improvement was $1.59 \mathrm{~cm}$ on the 10 $\mathrm{cm}$ pain scale. ${ }^{4}$ In the study by Kofotolis et al, the result found for pain was significant $(p<0.05)$ for Pilates participants compared with the trunk strengthening exercise group and the control group. Preassessment pain scores increased by halfand postassessment pain scores in the Pilates eight-week group. ${ }^{5}$ Preassessment pain scores increased by half and postassessment pain scores in the Pilates eight-week group. ${ }^{5}$ After the 14-week study protocol proposed by Patti et al, it was demonstrated a significant reduction $(p<0.001)$ of pain in the Pilates experimental group before study randomization $(13.7 \pm 5)$ and after completion. Pilates program $(6.5 \pm 4)$ and control group before study randomization
$(10.7 \pm 7.8)$ and after Pilates program completion ( $8.4 \pm 7.8)$, but the reduction was higher in the experimental group. ${ }^{14}$ Bhadauria et al, in their study comparing three types of interventions (Pilates, dynamic strengthening, and lumbar stabilization), found that pain did not significantly decrease in the Pilates group when compared with dynamic strengthening and lumbar stabilization groups, but intragroup (a) the reduction was significant $(p<0.001)$, from preassessment $(6.42 \pm 1.00)$ to postassessment $(1.33 \pm 0.98) .{ }^{15}$ In the article by Cruz-Díaz, et al, intervention groups showed improvement on pain at 6 and 12 weeks from baseline (mean PMG 3.3 and 2.1 ) and (mean PAG 2,1 and 1,70) with a $p<0.001$, while no changes were observed in control group (mean CG 5.06 and 4.96) $p=0.875$. A significant improvement in pain was also found in the study by Valenza et al, in patients who performed Pilates for 8 weeks, being observed a mean change of $2.3 \pm 1.9$ in current pain and of $2.0 \pm 1.8$. in the worst pain or the most painful period when compared with the control group. ${ }^{16}$

\section{Disability and Kinesiofobia}

Disability is another subject addressed in the articles analyzed, being involved and multifactorial explained by the difficulty or impossibility of performing tasks and activities because of pain. ${ }^{17}$ The most common way to measure is with the Roland- Morris disability questionnaire and the Oswestry disability index, and the Patient-Specific Functional Scale can also be used. Kinesiophobia, that is, fear of pain with any movement, ends up affecting self-care, household chores, work, social activities, and leisure. One of the most used 
Pilates and Lumbar Pain Schimidt et al. 303

Table 1 Summary of articles comparing different patient samples, interventions, and outcomes of the Pilates method in the treatment of nonspecific low back pain

\begin{tabular}{|c|c|c|c|c|c|}
\hline Article, year & Patients & Intervention & $\begin{array}{l}\text { Follow-up } \\
\text { time period }\end{array}$ & Outcome & Conclusion \\
\hline $\begin{array}{l}\text { (Da Luz } \\
\text { et al., } \\
2014)^{13}\end{array}$ & $\begin{array}{l}86 \text { patients (n } 43 \\
\text { per group) } \\
\text { G Mat Pilates } \\
\text { G equipment-based } \\
\text { Pilates }\end{array}$ & $\begin{array}{l}\text { The participants of both groups } \\
\text { received an individual and } \\
\text { supervised treatment. The first } \\
\text { session was to activate the } \\
\text { powerhouse. } \\
\text { The groups performed } 15 \text { to } 20 \\
\text { exercises on the ground (G Mat } \\
\text { Pilates) and in the equipment (G } \\
\text { equipment-based Pilates) per } \\
\text { session, with each exercise being } \\
\text { repeated } 10 \text { times }\end{array}$ & $\begin{array}{l}\text { The } \\
\text { intervention of } \\
12 \text { sessions for } \\
6 \text { weeks }\end{array}$ & $\begin{array}{l}\text { Pain intensity; } \\
\text { disability; Global } \\
\text { perceived effect; } \\
\text { kinesiophobia }\end{array}$ & $\begin{array}{l}\text { Equipment-based Pilates } \\
\text { was superior to Mat pilates } \\
\text { in the 6-month follow-up } \\
\text { for the outcomes of } \\
\text { disability and } \\
\text { kinesiophobia }\end{array}$ \\
\hline Article, year & Patients & Intervention & $\begin{array}{l}\text { Follow-up time } \\
\text { period }\end{array}$ & Outcome & Conclusion \\
\hline $\begin{array}{l}\text { (Natour et al., } \\
2014)^{4}\end{array}$ & $\begin{array}{l}60 \text { patients }(n=30 \\
\text { per group) } \\
G \text { experimental } \\
C \text { control }\end{array}$ & $\begin{array}{l}\text { G experimental: medication } \\
\text { treatment and treatment with } \\
\text { the Pilates method } \\
\mathrm{C} \text { control: Medication treatment } \\
\text { and did not undergo any other } \\
\text { intervention }\end{array}$ & $\begin{array}{l}\text { The } \\
\text { intervention } \\
\text { occurred twice } \\
\text { a week for } 90 \\
\text { days }\end{array}$ & $\begin{array}{l}\text { Pain intensity; } \\
\text { disability; quality of } \\
\text { life; satisfaction with } \\
\text { treatment; flexibility } \\
\end{array}$ & $\begin{array}{l}\text { The Plates method can be } \\
\text { used by patients with low } \\
\text { back pain to improve pain, } \\
\text { function and aspects } \\
\text { related to quality of life. In } \\
\text { this has harmful effects on } \\
\text { such patients addition, } \\
\text { method no }\end{array}$ \\
\hline $\begin{array}{l}\text { Kofotolis } \\
\text { et al., 2016) }\end{array}$ & $\begin{array}{l}101 \text { patients } \\
\text { G Pilates }(n=37) \\
\text { G Trunk } \\
\text { strengthening } \\
\text { exercise }(n=36) \\
\text { G Control }(n=28)\end{array}$ & $\begin{array}{l}\text { G Pilates: Mat Pilates exercise } \\
\text { G Trunk strengthening exercise: } \\
\text { Exercises for strengthening the } \\
\text { abdomen and for the back and } \\
\text { stretching } G \text { control: did not } \\
\text { participate in any form of } \\
\text { organized exercise }\end{array}$ & $\begin{array}{l}\text { Intervention of } \\
24 \text { sessions for } \\
8 \text { weeks }\end{array}$ & $\begin{array}{l}\text { Pain intensity; } \\
\text { disability; Quality of } \\
\text { life }\end{array}$ & $\begin{array}{l}\text { An 8-week Pilates program } \\
\text { improves quality of life and } \\
\text { reduced functional } \\
\text { disability more than either } \\
\text { a trunk strengthening } \\
\text { exercise program or } \\
\text { controls. }\end{array}$ \\
\hline $\begin{array}{l}\text { (Patti et al., } \\
2016)^{14}\end{array}$ & $\begin{array}{l}38 \text { patients }(n=19 \\
\text { per group) } \\
\text { G experimental } \\
\text { G control }\end{array}$ & $\begin{array}{l}\text { The G experimental group } \\
\text { completed a Pilates matwork } \\
\text { exercise program, under the } \\
\text { supervision of an exercise } \\
\text { specialist. The G control group } \\
\text { was managed only with a social } \\
\text { program and use of NSAIDS }\end{array}$ & $\begin{array}{l}\text { Intervention of } \\
14 \text { weeks }\end{array}$ & $\begin{array}{l}\text { Pain intensity; } \\
\text { disability; } \\
\text { posturography } \\
\end{array}$ & $\begin{array}{l}\text { The Pilates exercise } \\
\text { program yielded } \\
\text { improvements in pain and } \\
\text { posturography outcomes. }\end{array}$ \\
\hline $\begin{array}{l}\text { (Bhadauria, } \\
\text { Gurudut., } \\
\text { 2017) }\end{array}$ & $\begin{array}{l}44 \text { patients }(\mathrm{n}=12 \\
\text { per group) } \\
\mathrm{G} \text { Lumbar } \\
\text { stabilization } \\
G \text { Dynamic } \\
\text { strengthening } \\
\text { G Pilates }\end{array}$ & $\begin{array}{l}\text { All the groups performed } \\
\text { interferential current and hot } \\
\text { moist pack. } \\
\text { G lumbar stabilization: } 16 \text { lumbar } \\
\text { stabilization exercises and the } \\
\text { "hollowing' technique. G } \\
\text { dynamic strengthening: } 14 \\
\text { exercises for spinal extensor and } \\
\text { flexor muscle groups } \\
\text { G Pilates: activate the } \\
\text { powerhouse }\end{array}$ & $\begin{array}{l}\text { The } \\
\text { intervention } \\
\text { occurred in } 10 \\
\text { sessions in } 3 \\
\text { weeks }\end{array}$ & $\begin{array}{l}\text { Pain intensity; } \\
\text { disability; range of } \\
\text { motion; muscle } \\
\text { strength; }\end{array}$ & $\begin{array}{l}\text { There was reduction of } \\
\text { pain, improvement in } \\
\text { range of motion, } \\
\text { functional ability and core } \\
\text { strength in all the } \\
3 \text { exercise groups. } \\
\text { However, lumbar } \\
\text { stabilization proved to be } \\
\text { the most effective form of } \\
\text { exercise for chronic low } \\
\text { back pain. }\end{array}$ \\
\hline $\begin{array}{l}\text { (Cruz-Diaz } \\
\text { et al., 2017) }\end{array}$ & $\begin{array}{l}98 \text { patients } \\
\text { G Mat Pilates } \\
(n=34) \\
\text { G Equipment-based } \\
\text { Pilates }(n=34) \\
\text { G control }(n=30)\end{array}$ & $\begin{array}{l}\text { G Mat Pilates and G Equipment- } \\
\text { based Pilates: warm up, main } \\
\text { Pilates training activity and cool } \\
\text { down }\end{array}$ & $\begin{array}{l}\text { Intervention of } \\
12 \text { weeks }\end{array}$ & $\begin{array}{l}\text { Pain intensity; } \\
\text { disability; } \\
\text { kinesiophobia; } \\
\text { transversus } \\
\text { abdominis activation }\end{array}$ & $\begin{array}{l}\text { Pilates was effective in } \\
\text { improving pain, disability, } \\
\text { deep trunk muscles } \\
\text { activation and } \\
\text { kinesiophobia. The } \\
\text { equipment based Pilates } \\
\text { seems to provide faster } \\
\text { and better results } \\
\text { compared with Mat Pilates, } \\
\text { especially in the short term }\end{array}$ \\
\hline $\begin{array}{l}\text { (Valenza } \\
\text { et al., 2017) }\end{array}$ & $\begin{array}{l}54 \text { patients }(\mathrm{n}=27 \\
\text { per group) } \\
\text { G Experimental } \\
\text { G Control }\end{array}$ & $\begin{array}{l}\text { G experimental: Pilates exercise } \\
\text { program } \\
G \text { control: advice in the form of a } \\
\text { leaflet. }\end{array}$ & $\begin{array}{l}\text { Intervention of } \\
8 \text { weeks }\end{array}$ & $\begin{array}{l}\text { Pain intensity; } \\
\text { Disability; lumbar } \\
\text { mobility; flexibility; } \\
\text { balance; }\end{array}$ & $\begin{array}{l}\text { An 8-week Pilates exercise } \\
\text { program is effective in } \\
\text { improving disability, pain, } \\
\text { flexibility and balance in } \\
\text { patients with chronic } \\
\text { nonspecific low back pain. }\end{array}$ \\
\hline
\end{tabular}


instruments currently to evaluate this symptom is the Tampa Scale for Kinesiophobia (TKS). ${ }^{18}$ The article by da Luz et al assessed disability using the Roland-Morris Questionnaire. In the intragroup comparison, a significant difference was found ( $p=0.01$ ), except for kinesiophobia (assessed by the Tampa scale) in the Mat Pilates group in the middle group. Deadline. Comparison between groups showed significant improvement in disability outcomes (mean difference $=3.0$ points, $95 \%$ confidence interval $[\mathrm{CI}]=0.6-5.4)$, specific disability (mean difference $=-1.1$ points, $95 \% \mathrm{CI}=-2.0--0.1$ ) and kinesiophobia (mean difference $=4.9$ points, $95 \% \mathrm{CI}=1.6$ 8.2). In the equipment-based Pilates-treated group at six months follow-up. ${ }^{13}$ In their article, Natour et al also assessed disability by the Roland-Morris Questionnaire, improvement initially occurred in both groups, but the experimental group continued to improve while the control group remained unchanged. The difference found is significant for this outcome $(p<0.001)$, that is, a two-point improvement in the questionnaire score for the experimental group. ${ }^{4}$ For disability, Kofotolis et al indicated that the Pilates group had significant improvements compared with the trunk strengthening exercise group after 3 months of intervention. The Pilates group reported a significant increase in functional capacity from baseline assessment to half and from baseline assessment to final assessment, whereas the control group experienced a significant deterioration observed from baseline assessment to halfway. ${ }^{5}$ Disability was measured by the Oswestry Disability Index by Patti et al, noting a lower score reduction for the experimental group. ${ }^{14}$ Bhadauria et al had already used the same instrument to assess disability, finding a reduction in the questionnaire score in the Pilates group when the dynamic strengthening group, but this reduction was not significant. When compared within the group, the reduction was significant $(p<0.001)$ for Pilates at the beginning of the intervention $(28.17 \pm 13.55)$ and at the end of the intervention $(8.42 \pm 5.14) .{ }^{15}$ According to Cruz-Díaz et al, disability obtained favorable results in the Roland Morris Disability Questionnaire in the Pilates appliance group $(6.73 \pm 5.08$ and $4.76 \pm 4.9)$ and Pilates solo (7.94 \pm 5.12 and $6.35 \pm 5.3$ ) after 6 and 12 weeks, respectively, but the best result was in the appliance group ( $p<0,001)$, significant in the intra and intergroup comparison. In the assessment of kinesiophobia by TKS, the improvement also occurred at 6 and 12 weeks in both groups. In the appliance group, the mean scores (32) were higher at the end of the intervention compared with the solo group (31.73) and the control group (34.10). ${ }^{8}$ Valenza et al verified disability in their article using the Oswestry Disability Index $(p<0.001)$ and Roland-Morris Questionnaire (mean variation \pm standard deviation (SD) of $6.78 \pm 0$ and $2.40 \pm$ mean the difference between groups of $3.2 \pm 4.12$, $p=0.003$ ), finding an average change of 16.35 and 5.31 points, respectively, in the experimental group; this improvement was observed with 6 weeks of treatment. ${ }^{16}$

\section{Muscular Strength, Range of Movement and Flexibility}

Muscular strength disorders are often found in patients with low back dysfunction, and it is estimated that $>80 \%$ of all cases of low back pain are caused by weakness of the trunk muscles. ${ }^{19}$ Only Bhadauria et al assessed muscle strength by pressure biofeedback; as a result, they found no significant improvement in the Pilates group compared with the dynamic strengthening group and the stabilization group. Lower back, but showed significant improvement $(p<0.0001)$ within the Pilates group. In this same article, the range of motion was evaluated using the modified Schober test and it was found that the three interventions were beneficial in increasing the range of motion. ${ }^{15}$ Flexibility is pointed out as one of the causes that may be associated with nonspecific low back pain when there is no good condition of muscle stretching that contributes to the appearance of the symptoms and discomforts of lumbar dysfunction. ${ }^{20}$ The tests used in the articles analyzed to assess flexibility were the sit and reach test and finger to the ground. Natour et al, in their study, found no differences between the groups over time. The authors believe that the Pilates method improves flexibility, justifying that the instrument chosen to evaluate this outcome was not able to measure correctly. ${ }^{4}$ In the article by Valenza et al, the Pilates intervention group showed an improvement in flexibility, while the control group showed no significant difference (mean difference between groups $8.45 \pm 9.65 ; p=0.032$ ). The higher the value is the shortening of the trunk and lower limb muscles. ${ }^{16}$

\section{Quality of Life}

Low back pain has an essential impact on the life of the individual. The patient is depressed, anxious, and dissatisfied, characterizing a reduction in his QOL. The tools to assess QOL should enable the detection of changes in health conditions, the prognosis, risks, and benefits of a given therapeutic intervention. ${ }^{21} \mathrm{SF}-36$ is a generic measure of the QOL assessment that should be analyzed by comparing preintervention and postintervention scores for each patient individually. Natour et al, in their article, used this questionnaire to measure QOL, after a comparison between groups over time, and found a significant difference, favoring the experimental group in some domains of QOL such as functional capacity $(p<0.046)$, pain $(p<0.010)$ and vitality $(p<0.029) .{ }^{4}$ Kofotolis et al found in individuals in the Pilates group an increase in QOL in the domains vitality, social functioning, emotional role, physical role, general health, and mental health, from pre-evaluation to the intermediate evaluation and from the intermediate evaluation to postevaluation $(p<0.05)$ compared with the trunk strengthening exercise group. ${ }^{5}$

\section{Self-perception and Satisfaction}

Self-perception can be defined as the feeling that patients have regarding the changes in their lives due to the treatment received, interfering in the relationship between objective treatment outcomes and the degree of user satisfaction. ${ }^{22}$ In their study, Da Luz et al evaluated the global perceived effect through the global perceived effect scale, where the higher the score, the greater the recovery from the condition. We found no significant differences in the credibility and 
expectation of treatment for improvement between the Pilates Solo and Pilates appliance group. ${ }^{13}$ Factors that lead to satisfaction with treatment can be classified into psychosocial, physical, discomfort, and pain. Satisfied patients adhere more quickly to the treatment performed, not abandoning, and not changing the technique used. ${ }^{23}$ Natour et al, although not finding a significant difference between groups regarding satisfaction with treatment, observed a higher number of 'much better' responses on the Likert scale in the Pilates group. ${ }^{4}$

\section{Conclusions}

Based on this narrative review highlighting the state of the literature on this subject, we found useful results to clarify the influence of the Pilates method on nonspecific low back pain, considering its effects and benefits to patients. It is concluded that all techniques that were compared with Pilates are effective, being difficult to affirm the superiority of Pilates over them concerning pain and disability reduction and improving QOL. Finally, as can be observed in the studies analyzed, the Pilates method has demonstrated excellent results in pain perception and intensity, functional capacity, fear of movement, and the idea that movement can worsen the health perception, muscle strength, and flexibility. The satisfaction and adherence of this method as a treatment comes more and more, and the practice is indicated by doctors and health professionals. Pilates is a strong ally in the prevention and rehabilitation of low back pain due to the globality of its exercises.

\section{Conflict of Interests}

The authors have no conflict of interests to declare.

\section{References}

1 Kuijer W, Brouwer S, Preuper HR, Groothoff JW, Geertzen JH, Dijkstra PU. Work status and chronic low back pain: exploring the International Classification of Functioning, Disability and Health. Disabil Rehabil 2006;28(06):379-388

2 Wand BM, O'Connell NE. Chronic non-specific low back pain sub-groups or a single mechanism? BMC Musculoskelet Disord 2008;9(01):11

3 Machado PM, Alves MC, Hendler KG, et al. . Effectiveness of the Pilates method for individuals with nonspecific low back pain: clinical and electromyographic aspects. Motriz: J. Phys. Ed 2017; 23:4

4 Natour J, Cazotti LdeA, Ribeiro LH, Baptista AS, Jones A. Pilates improves pain, function and quality of life in patients with chronic low back pain: a randomized controlled trial. Clin Rehabil 2015;29(01):59-68

5 Kofotolis N, Kellis E, Vlachopoulos SP, Gouitas I, Theodorakis Y. Effects of Pilates and trunk strengthening exercises on healthrelated quality of life in women with chronic low back pain. J Back Musculoskeletal Rehabil 2016;29(04):649-659
6 Hayden JA, van Tulder MW, Malmivaara A, Koes BW. Exercise therapy for treatment of non-specific low back pain. Cochrane Database Syst Rev 2005;x(03):CD000335

7 Da Silva ACLG, Mannrich G. Pilates on rehabilitation: a systematic review. Phys Ther Movement 2009;x(22):449-455

8 Cruz-Díaz D, Bergamin M, Gobbo S, Martínez-Amat A, HitaContreras F. Comparative effects of 12 weeks of equipment based and mat Pilates in patients with Chronic Low Back Pain on pain, function and transversus abdominis activation. A randomized controlled trial. Complement Ther Med 2017;33:72-77

9 Muscolino JE, Cipriani IS. Pilates and the "powerhouse"- I. J Bodyw Mov Ther 2004;8(01):15-24

10 Yamato TP, Maher CG, Saragiotto BT, et al. . Pilates for low back pain. Cochrane Database Syst Rev 2015;(07):CD010265

11 Qaseem A, Wilt TJ, McLean RM, Forciea MAClinical Guidelines Committee of the American College of Physicians. Noninvasive treatments for acute, subacute, and chronic low back pain: a clinical practice guideline from the American College of Physicians. Ann Intern Med 2017;166(07):514-530

12 Paolucci T, Attanasi C, Cecchini W, Marazzi A, Capobianco SV, Santilli V. Chronic low back pain and postural rehabilitation exercise: a literature review. J Pain Res 2018;12:95-107

13 da Luz MA Jr, Costa LO, Fuhro FF, Manzoni AC, Oliveira NT, Cabral CM. Effectiveness of mat Pilates or equipment-based Pilates exercises in patients with chronic nonspecific low back pain: a randomized controlled trial. Phys Ther 2014;94(05):623-631

14 Patti A, Bianco A, Paoli A, et al. . Pain Perception and Stabilometric Parameters in People With Chronic Low Back Pain After a Pilates Exercise Program: A Randomized Controlled Trial. Medicine (Baltimore) 2016;95(02):e2414

15 Bhadauria EA, Gurudut P. Comparative effectiveness of lumbar stabilization, dynamic strengthening, and Pilates on chronic low back pain: randomized clinical trial. J Exerc Rehabil 2017;13(04): 477-485

16 Valenza MC, Rodríguez-Torres J, Cabrera-Martos I, Díaz-Pelegrina A, Aguilar-Ferrándiz ME, Castellote-Caballero Y. Results of a Pilates exercise program in patients with chronic non-specific low back pain: a randomized controlled trial. Clin Rehabil 2017; 31(06):753-760

17 Da Silva GV, Costa LO, Fuhro FF, et al. . Disfunção muscular e lombalgia em pilotos de helicóptero. Fisioter Bras 2005;6(04): 281-289

18 Siqueira FB, Teixeira-Salmela LF, Magalhães LC. Análise das propriedades psicométricas da versão brasileira da escala tampa de cinesiofobia. Acta Ortop Bras 2007;15(01):19-24

19 Silva PHB, da Silva DF, Oliveira JKS, et al. . The effect of the Pilates method on the treatment of chronic low back pain: a clinical, randomized, controlled study. BrJP 2018;1(01):21-28

20 Polito MD, Maranhão Neto G, Lira VA. Componentes da aptidão física e sua influência sobre a prevalência de lombalgia. $\mathrm{R}$ Bras Ci e Mov. 2008;11(02):35-40

21 Adorno ML, Brasil-Neto JP. Assessment of the quality of life through the SF-36 questionnaire in patients with chronic nonspecific low back pain. Acta Ortop Bras 2013;21(04):202-207

22 Bandeira M, Andrade MCR, Costa CS, et al. . Percepção dos pacientes sobre o tratamento em serviços de saúde mental: validação da Escala de Mudança Percebida. Psicol Reflex Crit 2011;24(02):236-244

23 Figueiredo FMA. Efeitos na qualidade de vida da Associação da Acupunctura ao tratamento conservador da lombalgia inespecífica crónica. 2008. Dissertação de Mestrado 